\title{
GREEN REDUCTION OF SOME AROMATIC NITRO COMPOUNDS BY IMMOBILIZED BAKER'S YEAST
}

\author{
Sharma S.K. ${ }^{1}$ \\ ${ }^{1}$ Assistant Professor, \\ Department of Pure \& Applied Chemistry, \\ University of Kota, Kota, \\ Rajasthan, India
}

\author{
Sharma A. ${ }^{2}$ \\ ${ }^{2}$ Assistant Professor, \\ Department of Pure \& Applied Chemistry, \\ University of Kota, Kota, \\ Rajasthan, India
}

Corresponding Author : Sharma S.K.

\begin{abstract}
Green chemical reduction of selected aromatic nitro compounds like o-nitrobenzoic acid, m-nitrobenzoic acid and pnitrobenzoic acid will be done by involving microbial transformation. In microbial transformation Baker's Yeast (Saccharomyces cerevisiae) is used in immobilized form. Utilisation of baker's yeast for reduction of nitro compounds is cost effective and environmental friendly. The reduction products will be isolated and purified by chromatographic techniques and characterized on the basis of spectral analysis viz. IR, NMR spectral data.
\end{abstract}

KEYWORDS: Baker's Yeast, Chromatographic technique, Green reduction, Microbial transformation, Spectroscopic technique.

\section{INTRODUCTION}

Immobilized enzymatic methods used for the resolution of recemic mixture of amino acids at industrial level were initially done by Tanabe, Seiyaku Company, Japan. For separation of recemic mixture of DL-N-acetyl amino acids, enzyme amylase was used which carried out the deacetylation of L-form only, which was separated out easily. The remaining $\mathrm{D}$ component of amino acid was reracemized and the racemate is subjected to deacyclation. Thereafter the cycle is repeated till resolution is complete. The process is applicable for resolution of all DL-amino acids. One of the immobilized enzyme technique uses a polymer matrix DEAE-Sephdex having ionic binding with enzymes entrapping them as microdroplets. Enzyme glucose isomerase ${ }^{1}$ is immobilized and is used for effective conversion of glucose syrups to fructose syrups. Historically, invertase is perhaps the first enzyme reported in an immobilized form ${ }^{2}$. A large number of immobilized invertase systems have been patented $^{3}$. The possible use of whole cells of yeast as a source of invertase was demonstrated by
D'Souzaand Nadkarni in $1978^{4}$. The enzymes have been immobilized using the whole cells of Escherichia coli. This was considered as the first industrial application of an immobilized microbial cell. The initial process made use of polyacrylamide entrapment which was latter substituted with carrageenan treated with glutaraldehyde and hexamethylenediamine. Kyowa Hakko Kogyo Co. used Dualite A7. Phenol formaldehyde resin has wise like been used for adsorbing aspartase in a continuous process 5 . Other important Firms using immobilized enzymes on commerical basis include Mitsubishi petrochemical Co. ${ }^{6}$ and Purification Engineering $\mathrm{Inc}^{7}$. Some other firms, like Tanabe Sciyaku and Kyowa Hakk of Japan, have used the immobilized fumarase for the production of pharmaceutical malic $\mathrm{acid}^{8}$. Pharmaceutical industries have utilized the concept of immobilized enzymes technique using penicillin acylase enzyme for the production of 6-aminopenicillanic acid (6APA) by the deacylation of the side chain in either penicilln $\mathrm{G}$ or $\mathrm{V}^{9}$. More than $50 \%$ of 6 -APA is being produced today enzymatically by using immobilized enzyme technology. Immobilized enzymes are also 
finding used in the detecting Heroin and its Metabolites 10 and last but not least in hazardous waste treatment ${ }^{11-12}$.Asymmetric synthesis of amino acids, steroids etc through transformation by oxidoreductase enzyme have significance in the field of biotechnology.

Oxidoreductases enzyme has gained vital importance in the field of clinical diagnosis as being usable as biosensors. For deoxygenation of beverages and glucose removal from egg before dehydration for preventing Maillard reaction glucose oxidase enzyme in its immobilized form is used. Future applications for oxidoreductases can be in areas as diverse as polymer synthesis, pollution control and oxygenation of hydrocarbons ${ }^{13-14}$. One of the major limitations in the use of enzyme which act on macromolecular substrates or particulate or colloidal substrates like starch or cellulose pectin or proteins has been the low retention of their realistic activities with natural substrate due to the steric hindrance. Efforts have been made to minimize these problems by attaching enzymes through spacer arms ${ }^{15}$.

The immobilization of whole cells or enzymes enhances the operational stability. Immobilization is beneficial on several accounts and affords easier isolation of the products. In addition, reuse of catalyst is often possible. The product formation rates in such cases are usually high ${ }^{16}$, not only due to minimal inhibitory influences but also because of high cell population. Continuous operation can be performed easily under these conditions since the immobilized cells can be easily removed from the reaction medium and thus reused repeatedly.

In the present work the aromatic nitro compounds viz. $o$-nitrobenzoic acid, m-nitrobenzoic acid ans $p$-nitrobenzoic acid were reduced by using immobilized Baker's Yeast in water. The immobilized BY was obtained by immobilizing BY in polyacrylamide gel.

\section{MATERIAL \& METHODS}

For green reduction of nitro compounds $o$ nitrobenzoic acid, $m$-nitrobenzoic acid, $p$ nitrobenzoic acid, Baker's Yeast, Acrylamide, N,N'methylene bis acrylamides, N,N,N,N-tetra methyl ethylene diamine (TEMED), Trihydroxy methyl amino methane, ammonium per sulphate and sucrose were used of AR grade(Sigma Aldrisch).

\subsection{General Procedure}

To a water-suspension $(100 \mathrm{ml})$ of $\mathrm{ImBY}$ (Immobilized Baker's Yeast) at $30^{\circ} \mathrm{C}$. After $30 \mathrm{~min}$ substrate $(2 \mathrm{~m} \mathrm{~mol})$ separately dissolved in absolute alcohol (minimum quantity) was added. The resulting solution was magnetically stirred for suitable period. The suspension changes its colour from orange to yellow during the course of reaction.

After the completion of the reaction the resulting mixture was filtered. The water was removed from the solution by distillation. The residue was then extracted repeatedly with diethyl ether. The ether layer was allowed to evaporate. After evaporation product was isolated, purified and characterized by combined application chromatographic techniques and spectroscopy.

\subsection{Immobilization of Baker's Yeast in polyacrylamide gel}

Laboratory as well as industrial scale immobilization of BY using various types of supports such as polyacrylamide, cellulose, agar, alignate ${ }^{17}$, chitosan $^{18}$, keisgular ${ }^{19}$ K-carrageenan ${ }^{20}$, polyurethane ${ }^{21}$ and montmorillonite $\mathrm{k}-10$ has been well reported. These chemicals provide have been porous networks of polymer for entrapment. However for the present work the Baker's Yeast immobilized in polyacrylamide gel has been used. Since it is easy to prepare and change the characteristic properties of polyacrylamide gel as an experimental equipments.

The polyacrylamide gel incorporting BY was prepared by using the following solutions-
1. $\quad 1.0 \mathrm{ml}$ of solution $\mathrm{E}$
2. $\quad 0.5 \mathrm{ml}$ of solution $\mathrm{F}$
3. $\quad 0.5 \mathrm{ml}$ of solution $\mathrm{G}$
4. $\quad 2.0 \mathrm{ml}$ of solution $\mathbf{H}$

The composition of the above solutions were as follows-

Solution E: Acrylamide 10 gm and N, N'-methylene bis acrylamide $2.5 \mathrm{gm}$ in $100 \mathrm{ml}$ double distilled water (DDW)

Solution F: Tris $5.98 \mathrm{gm} *$, TEMED** $0.46 \mathrm{ml}$ and $1 \mathrm{~N} \mathrm{HCl} 48 \mathrm{ml}$ to $100 \mathrm{ml}$ solution.

Solution G: APS (Ammonium per sulphate) $560 \mathrm{mg}$ in $100 \mathrm{ml}$ double distilled water.

Solution H: sucrose $34.2 \mathrm{gm}$ in $100 \mathrm{ml}$ DDW.

$*$ Tris $=$ Trihydroxy methyl amino methane

** TEMED $=\mathrm{N}, \mathrm{N}, \mathrm{N}$ ', N" - tetra methyl ethylene diamine.

For preparation of 5\% polyacrylamide gel above solutions were mixed in the ratio in following manner as mentioned earlier.

\section{$\mathbf{E}+\mathbf{F}+\mathbf{H}+$ (Baker's Yeast) $+\mathbf{G}$}

As the solution of APS (Soulution G) is free radical generator, was added after $\mathrm{BY}$ was mixed well in solution containing mixture of of $\mathrm{E}, \mathrm{F}, \& \mathrm{H}$ is because the gel formation is a free radical initiated process.

The Chemical structure \& pictorial depiction of the entrapment of the BY are shown in the on Fig.1. 


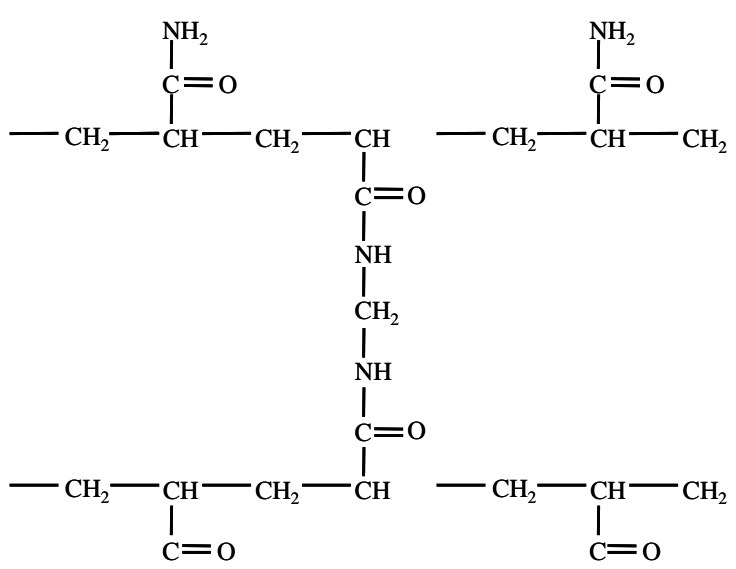

Fig.1: Structure of crosslinked polyacrylamide $\&$ bis acrylamide

\section{RESULTS \& DISCUSSION}

Immobilized Baker's Yeast reduced products i.e. $o$-aminobenzoic acid, $m$-aminobenzoic acid and $p$-aminobenzoic acid were obtained in reasonably good yields. TLC was used to find out the purity of products. The identity of products was further confirmed on the basis of IR and NMR data have been given in Table 1,2 and 3.The IR spectra were recorded on a NICOLET (USA) make FTIR spectrophotometer. The $\mathrm{H}^{1}$ NMR was recorded on a JOEL-300ml FTNMR (Japan).

Table 1: Characterization table for reduction of $o$-nitrobenzoic acid

\begin{tabular}{|c|c|c|c|c|c|}
\hline $\begin{array}{c}\text { Name of } \\
\text { substrate }\end{array}$ & $\begin{array}{l}\text { M.P. } \\
\left({ }^{0} \mathrm{C}\right)\end{array}$ & IR Data $\left(\mathrm{cm}^{-1}\right)$ & $\begin{array}{l}\text { NMR Data } \\
\text { ( } \delta \text { value) }\end{array}$ & $\begin{array}{c}\text { Product } \\
\text { Identified }\end{array}$ & Yield (\%) \\
\hline $\begin{array}{c}o \text {-nitro } \\
\text { benzoic } \\
\text { acid }\end{array}$ & 146 & $\begin{array}{l}\text { 3083-3070s (Ar-H stretching) } \\
\text { 3059s (C-H stretching) } \\
\text { 3278,3156d (N-Hsym.stretch) } \\
\text { 1670b (N-H bending) } \\
\text { 1290s (C-N stretching) } \\
\text { 3862-3278s (O-H stretching) } \\
1737 \text { s (-C=O stretching) } \\
1226 \text { s (-C-O stretching) } \\
\text { 988-920 b (O-H bending) } \\
808-734 \text { (v,s) (o-substitution) }\end{array}$ & $\begin{array}{l}8.9(1 \mathrm{H}), \\
4.5(2 \mathrm{H}), \\
7.7(1 \mathrm{H}), \\
6.9(1 \mathrm{H}), \\
6.6(1 \mathrm{H}), \\
5.9(1 \mathrm{H})\end{array}$ & $\begin{array}{l}o \text {-amino } \\
\text { benzoic } \\
\text { acid }\end{array}$ & 90.7 \\
\hline
\end{tabular}

Table 2: Characterization table for reduction of $m$-nitrobenzoic acid

\begin{tabular}{|c|c|c|c|c|c|}
\hline $\begin{array}{c}\text { Name of } \\
\text { substrate }\end{array}$ & $\begin{array}{l}\text { M.P. } \\
\left({ }^{\circ} \mathrm{C}\right)\end{array}$ & IR Data $\left(\mathrm{cm}^{-1}\right)$ & $\begin{array}{c}\text { NMR Data } \\
\text { ( } \delta \text { value) }\end{array}$ & $\begin{array}{c}\text { Product } \\
\text { Identified }\end{array}$ & Yield (\%) \\
\hline $\begin{array}{l}m \text {-nitro } \\
\text { benzoic } \\
\text { acid }\end{array}$ & 174 & 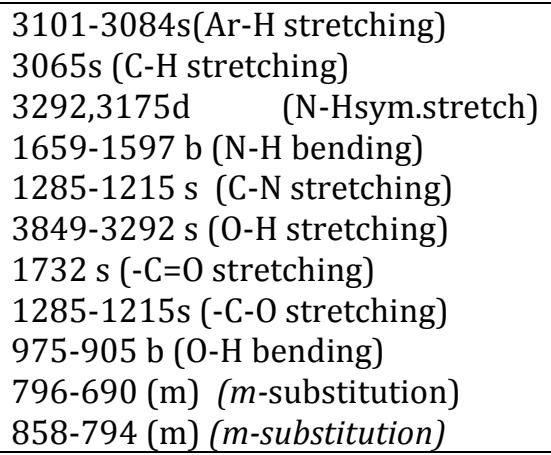 & $\begin{array}{c}9.2-10.5(1 \mathrm{H}) \\
3.8(1 \mathrm{H}) \\
7.2(1 \mathrm{H}) \\
6.6(1 \mathrm{H}) \\
5.2(1 \mathrm{H}) \\
4.9(1 \mathrm{H})\end{array}$ & $\begin{array}{c}m \text {-amino } \\
\text { benzoic } \\
\text { acid }\end{array}$ & 91.4 \\
\hline
\end{tabular}


Table 3: Characterization table for reduction of $p$-nitrobenzoic acid

\begin{tabular}{|c|c|c|c|c|c|}
\hline $\begin{array}{c}\text { Name of } \\
\text { substrate }\end{array}$ & $\begin{array}{l}\text { M.P. } \\
\left({ }^{0} \mathrm{C}\right)\end{array}$ & IR Data $\left(\mathrm{cm}^{-1}\right)$ & $\begin{array}{l}\text { NMR Data } \\
\text { ( } \delta \text { value) }\end{array}$ & $\begin{array}{c}\text { Product } \\
\text { Identified }\end{array}$ & Yield (\%) \\
\hline $\begin{array}{l}p \text {-nitro- } \\
\text { benzoic } \\
\text { acid }\end{array}$ & 188 & $\begin{array}{l}\text { 3104-3073 (Ar-H stretching) } \\
\text { 3070s (C-H stretching) } \\
\text { 3294,3176d(N-Hsym.stretch) } \\
\text { 1693-1673 b (N-H bending) } \\
\text { 1361-1334 s (C-N stretching) } \\
\text { 3852-3294 s (O-H stretching) } \\
1723 \mathrm{~s}(-\mathrm{C}=0 \text { stretching) } \\
\text { 1275-1200s (-C-O stretching) } \\
\text { 1066-921b (O-H bending) } \\
\text { 882-829(m) (p-substitution) }\end{array}$ & $\begin{array}{l}8.9(1 \mathrm{H}) \\
5.1(2 \mathrm{H}) \\
6.7(2 \mathrm{H}) \\
5.5(2 \mathrm{H})\end{array}$ & $\begin{array}{l}p \text {-amino } \\
\text { benzoic } \\
\text { acid }\end{array}$ & 93.2 \\
\hline
\end{tabular}

\section{CONCLUSIONS}

1. Reduction of nitro compounds by baker's yeast is eco- friendly, regio- and stereo selective processes. 2. The use of immobilized Baker's yeast (ImBY) as biocatalyst has several advantages such as removal of the biocatalyst from the reaction mixture is easy and its repeated use is also possible.

Acknowledgements : Authors wish to thank the Head, Department of Pure \& Applied Chemistry, University of Kota, Kota for providing the necessary facilities.

\section{REFERENCES}

1. W. Carasik and J.O. Carroll, Food Techno., (1983) 37, 85-91.

2. J.M. Nelson and E.G. Griffin, J. Am. Chem. Soc., (1916) 38, 1109-1115.

3. S.F. D'Souza and G. Nadkarni, Hindustan Antibiot. Bull., (1978) 80, 68-73.

4. B.S. Kubal, K. Sankaran and S.F. D'Souza, J. Microbiol. Biotechnol., (1990) 4, 98-102.

5. H. Samejima, K. Kimura and Y. Ado, Biochimie., (1980) 62, 299-315.

6. J. Tramper, Trends Biotechnol., (1985) 3, 4550.Chibata, Linko, $P$ and Larinkari, J., Applied Science Publishers, (1989) 2, 1-39.

7. M. Pastore and F. Morisi, Methods Enzymol, (1976) 44, 822-844.

8. P.J. Holt et al. Anal. Chem., (1996) 68, $1877-$ 1882.

9. W.C. Kuo and T.Y. Shu "Biological Pretreatment of Wastewater Containing Sulfate Using Anaerobic Immobilized Cells" (2004).

10. R.D. Tyagi and K. Vembu "Wastewater Treatment by Immobilized Cells" (1990).

11. P.S. Bokar, S.B. Thadani, and S. Ramachandran, Hindustan Antibiot. Bull., (1978) 20, 81-91.

12. S.W. May and S.R. Padgette, Biotechnology, (1983) 1, 677-686.

13. Carlson, G.C. Hgill and N.F. Olson, Enzyme Microb. Technol., (1986) 8, 642- 650.

14. T. Sato, Y. Nishida, T. Tosa and I. Chibata, Biotechnol., (1984) 1, 39.

15. M. Kierstan and C. Buke, Biotechnol. Bioeng., (1977)19, 387-397.
16. Zhang, Yanjun; Tian, Feng; Chen, Shiqian ,Junshi Yixue Kexueyuan Yuankan, (2002) 26(3), 225.

17. Stadler, Johann Germany "Immobilization of Microorganisms or Enzymes on Kieselguhr" Ger. Offen. DE 132 (2002).

18. 19. T. Sato, Y. Nishida, T. Tosa and I. Chibata, Biochemica at Biophysica Acta, (1979) 570, 179-185.

19. O. Lerenz; F. Haulena and G. Rose. Biotechnol. Bioeng. (2004) 29(3), 388-391.

20. A.E.P.M. Sorrilha, M. Margues, I. Joekes, P.J.S. Moran and J.A.R. Rodrigues, Biog. Med. Chem. Lett., (1992) 2, 191-196. 